\title{
Classical and molecular cytogenetics of Belontia hasselti (Perciformes: Osphronemidae): Insights into the $\mathrm{ZZ/ZW}$ sex chromosome system
}

\author{
PATCHARAPORN CHAIYASAN ${ }^{1}$, BOONYADA MINGKWAN ${ }^{1}$, SITTHISAK JANTARAT ${ }^{2}$, \\ CHATMONGKON SUWANNAPOOM ${ }^{3}$, MARCELO DE BELLO CIOFFI ${ }^{4}$, THOMAS LIEHR, \\ SUCHEELA TALUMPHAI ${ }^{6}$, ALONGKLOD TANOMTONG ${ }^{1}$, WEERAYUTH SUPIWONG ${ }^{7,}$ \\ ${ }^{1}$ Department of Biology, Faculty of Science, Khon Kaen University. Muang, Khon Kaen 40002, Thailand \\ ${ }^{2}$ Department of Science, Faculty of Science and Technology, Prince of Songkla University, Pattani Campus. Muang, Pattani 94000, Thailand \\ ${ }^{3}$ Department of Fishery, School of Agriculture and Natural Resources, University of Phayao. Muang, Phayao 56000, Thailand \\ ${ }^{4}$ Departamento de Genética e Evolução, Universidade Federal de São Carlos (UFSCar). Rodovia Washington Luiz Km. 235, C.P. 676, São Carlos, SP \\ 13565-905, Brazil \\ ${ }^{5}$ Jena University Hospital, Friedrich Schiller University, Institute of Human Genetics. Am Klinikum 1, D-07747 Jena, Germany \\ ${ }^{6}$ Major Biology, Department of Science and Technology, Faculty of Liberal Arts and Science, Roi Et Rajabhat University. Roi Et 45120, Thailand \\ ${ }^{7}$ Faculty of Interdisciplinary Studies, Khon Kaen University. Nong Khai Campus. Muang, Nong Khai 43000, Thailand. Tel.: +66-91-0600425, \\ Fax: +66-42-415699, "email: supiwong@hotmail.com
}

Manuscript received: 11 November 2020. Revision accepted: 7 January 2021.

\begin{abstract}
Chaiyasan P, Mingkwan B, Jantarat S, Suwannapoom C, Cioffi MDB, Liehr T, Talumphai S, Tanomtong A, Supiwong W. 2021. Classical and molecular cytogenetics of Belontia hasselti (Perciformes: Osphronemidae): Insights into the ZZ/ZW sex chromosome system. Biodiversitas 22: 546-554. Karyotype of Java combtail fish, Belontia hasselti, from To Daeng peat swamp forest, Narathiwat Province, southern Thailand, was studied for the first time. Mitotic chromosome preparations were prepared directly from kidney cells from ten male and ten female fish. Conventional staining, NOR banding, and molecular cytogenetics with fluorescence in situ hybridization (FISH) using $5 \mathrm{~S}$ and $18 \mathrm{~S}$ rDNAs, as well as microsatellites $\mathrm{d}(\mathrm{CA})_{15}$ and $\mathrm{d}(\mathrm{CAC})_{10}$ as probes were applied. The diploid chromosome number (2n) was 48 and a female heterogametic sex chromosome system (ZZ/ZW) is suggested. The fundamental numbers (NF) were 48 and 49 in males and females, respectively. The karyotype of males comprised 48 telocentric chromosomes while the female ones were composed of one metacentric and 47 telocentric chromosomes. A single Ag-NOR-bearing chromosomal pair was identified. The NOR positions were characterized at the interstitial sub-centromeric region of pair 13, which coincided with signals of $18 \mathrm{~S}$ rDNA and $\mathrm{d}(\mathrm{CAC})_{10}$ probes. The $5 \mathrm{~S}$ rDNA signals were located at interstitial sites of the largest telocentric pair. Microsatellite $\mathrm{d}(\mathrm{CA})_{15}$ repeats were highly distributed throughout almost all entire chromosomes except for centromeric regions on some chromosome pairs, including sex chromosomes. The present study is a novel report for a ZZ/ZW sex chromosome system of this fish family in Thailand.
\end{abstract}

Keywords: Ag-NOR staining, Belontia hasselti, cytogenetics, fluorescence in situ hybridization (FISH), karyotype

\section{INTRODUCTION}

Java combtail fish, Belontia hasselti belongs to the family Osphronemidae, subfamily Belontiinae. This subfamily is represented only by genus Belontia, and two species $B$. hasselti and $B$. signata, are native from freshwater habitats in Southeast Asia, and Sri Lanka (Froese and Pauly 2014). Mostly the species occur in acidic freshwater biotopes with little water movement, particularly, in ancient forest peat swamps in which the water is stained dark-brown by humic acids and other chemicals released from decaying organic material (Kottelat 2013). In Thailand, B. hasselti is endemic in the To Daeng peat swamp forest.

Cytogenetic studies demonstrated a huge karyotypic diversity for the family Osphronemidae. The overall data showed that $2 \mathrm{n}$ ranges from 16 in Sphaerichthys osphromenoides to 48 chromosomes in serval species as outlined in Table 1. Variations in karyotypic formula in the two species and their sub-populations result from differences in chromosome morphology.
Conventional staining technique has been used to determine chromosome number and karyotype composition. Structure, number, type, size, and morphology of a nucleolar organizer region (NOR) may be specific to populations, species, and subspecies. NORstaining is frequently used to compare variations, as well as to identify and explain specifications. Molecular cytogenetic experiments have demonstrated that NORs are the chromosomal site of gene coding for $5.8 \mathrm{~S}, 18 \mathrm{~S}$, and $28 \mathrm{~S}$ rRNA, in humans and several mammalian species. NORs can be used as markers for evolutionary chromosome studies (Gornung 2013; Gálvez et al. 2018). Recently, molecular cytogenetic studies using fluorescence in situ hybridization (FISH) for mapping repetitive DNA sequences have provided important contributions to the characterization of biodiversity and the evolution of divergent fish groups (Cioffi et al. 2015). However, conventional cytogenetic and FISH techniques to investigate the chromosomal distribution of repetitive DNA sequences on $B$. hasselti have not yet been performed. 
Accordingly, the present study is the first cytogenetic report on B. hasselti from Thailand, and is accomplished with both classical and molecular cytogenetics. The study moves forward our understanding of both the karyotype evolution mechanisms and speciation in the genus Belontia, and increases the knowledge available for implementation of polyploidy manipulation, hybridization, sex control, and other potential genetic improvements in the future.

\section{MATERIALS AND METHODS}

\section{Sample collection}

Ten males and ten females of Belontia hasselti were obtained from the To Daeng peat swamp forest, Narathiwat Province, Thailand. The fish were transferred to laboratory aquaria and kept under standard conditions for seven days before experimentations. The procedures followed ethical protocols, with anesthesia conducted by keeping samples in the freezer before euthanasia, as approved by the Institutional Animal Care and Use Committee of Khon Kaen University, based on the Ethics of Animal Experimentation of the National Research Council of Thailand ACUC-KKU-90/60.

\section{Chromosome preparation, Giemsa's staining and Ag- NORs banding technique}

Metaphase chromosomes were directly prepared in vivo as following Supiwong et al. (2012a, 2013b, 2015) and Kasiroek et al. (2017). Subsequently, chromosomes were stained with $20 \%$ Giemsa solution and $50 \%$ silver nitrate for Ag-NOR banding (Supiwong et al. 2012b; Getlekha et al. 2017; Chaiyasan et al. 2018).

\section{Chromosome checking}

Twenty metaphases of each specimen were selected and photographed. The length of the short arm chromosome (Ls) and the long arm chromosome (Ll) were measured from 20 perfect metaphase plates of each sex, while the length of the total arm chromosome (LT) was calculated $(\mathrm{LT}=\mathrm{Ls}+\mathrm{Ll})$. The relative length $(\mathrm{RL})$, the centromeric index $(\mathrm{CI})$, and standard deviation (SD) of RL and CI were estimated. The CI (q/p + q) between 0.50-0.59, 0.60-0.69, $0.70-0.89$, and $0.90-1.00$ are described as metacentric (m), submetacentric $(\mathrm{sm})$, acrocentric (a), and telocentric (t) chromosomes, respectively. The fundamental number (NF) was obtained by assigning a value of 2 to the $\mathrm{m}$, sm and a chromosomes and 1 to the $\mathrm{t}$ chromosome. All data were used in karyotyping and diagramming (Tanomtong et al. 2014; Chooseangjaew et al. 2017).

\section{Fluorescence in situ hybridization (FISH)}

FISH was performed on metaphase chromosome spreads with specific probes for $5 \mathrm{~S}$ and $18 \mathrm{~S}$ rDNAs under highly stringent conditions (Rodrigues et al. 2012; Maneechot et al. 2016). Both rDNA probes were directly labeled with the Nick-translation Labeling Kit (Jena Bioscience, Jena, Germany), using the fluorescent labels Atto488 (18S rDNA) and Atto550 (5S rDNA), according to the manufacturer's manual (Supiwong et al. 2017).
The usage of microsatellites $\mathrm{d}(\mathrm{CA})_{15}$, and $\mathrm{d}(\mathrm{CAC})_{10}$ probes described by Cioffi et al. (2011) was followed with slight modifications. Sequences were directly labeled with $\mathrm{Cy} 3$ at $5^{\prime}$ terminal during synthesis by Sigma (St. Louis, MO, USA). FISH was performed on mitotic chromosome spreads (Xu et al. 2017) under highly stringent conditions, as previously reported (Supiwong et al. 2017). The evaluation was carried out on an epifluorescence microscope Olympus BX50 (Olympus Corporation, Ishikawa, Japan).

\section{RESULTS AND DISCUSSION}

\section{Diploid chromosome number (2n), fundamental number (NF) and karyotype of Belontia hasselti}

The model diploid number of $B$. hasselt $i$ was $2 n=48$ chromosomes for both the sexes. The male karyotype was composed of 48 telocentric chromosomes (Figure 1.A-B), while females presented 47 telocentric and one large and unpaired metacentric chromosome (Figure 1.C-D), identified as the $\mathrm{W}$ chromosome. In addition to this, the female karyotype showed an exclusive telocentric chromosome, and the smallest chromosome was identified as the $\mathrm{Z}$ chromosome (Figure 1). Hence, a ZZ/ZW sex chromosomal heteromorphism was identified, with a large metacentric W-chromosome, which was similar in size to the first pair of karyotype complement (Figure 3 ). The NF were 48 and 49 in males and females, respectively (Figure 1, Table 1).

\section{Chromosome marker of Belontia hasselti}

The determination of a chromosome marker for this species was firstly obtained by Ag-NOR staining. The nucleolar organizer regions (NORs) were mapped to interstitial subcentromeric positions of the telocentric chromosome pair 13 (Figure 1 E-H).

\section{Patterns of $5 \mathrm{~S}$ and $18 \mathrm{~S}$ rDNAs in Belontia hasselti}

The 5S rDNA sequences were mapped at interstitial positions near the centromeres of the telocentric pair 1 (the first pair). The $18 \mathrm{~S}$ rDNA probe showed coincident hybridization signals of NOR-carrying chromosomes, at the interstitial subcentromeric regions on the telocentric chromosome pair 13 (Figure 2.A-B).

\section{Patterns of microsatellite $\mathrm{d}(\mathrm{CA})_{15}$ and $\mathrm{d}(\mathrm{CAC})_{10}$ repeats in Belontia hasselti}

The mapping of microsatellite repeats on the chromosomes of $B$. hasselti showed that $\mathrm{d}(\mathrm{CA})_{15}$ signals were observed on all chromosome pairs. These signals were distributed throughout the whole chromosomes except for centromeric regions of some pairs (pairs 2, 4, 8, 10, 15, and sex chromosomes in both sexes) (Figure 2.C-D). In turn, microsatellite $\mathrm{d}(\mathrm{CAC})_{10}$ was highly accumulated at the interstitial subcentromeric region on chromosome pair 13, which corresponds to the NOR position and 18S rDNA patterns (Figure 2.E-F). 
Table 1. Cytogenetics review in the family Osphronemidae

\begin{tabular}{|c|c|c|c|c|c|c|}
\hline Species & $2 n$ & $\mathbf{N F}$ & Karyotype formula & Ag-NORs & Sex-chromosome & Reference \\
\hline \multirow[t]{2}{*}{ Belontia hasselti } & 48 & 48 & $48 \mathrm{t}$ & 2 & $\mathrm{ZZ}, \mathrm{M}$ & Present study \\
\hline & 48 & 49 & $1 m+47 t$ & 2 & $\mathrm{ZW}, \mathrm{F}$ & Present study \\
\hline \multirow[t]{2}{*}{ Betta splendens } & 42 & - & - & - & - & Arai (2011) \\
\hline & 42 & $45-56$ & $12 \mathrm{sm}+14 \mathrm{st} / \mathrm{a}+16 \mathrm{a} / \mathrm{t}$ & - & - & Grazyna et al. (2008) \\
\hline Colisa chuna & 46 & 66 & $20 \mathrm{~m}+26 \mathrm{st} / \mathrm{a}$ & - & - & Grazyna et al. (2008) \\
\hline \multirow{3}{*}{ Colisa fasciata } & 48 & 48 & $48 \mathrm{a}$ & - & - & Grazyna et al. (2008) \\
\hline & 48 & 68 & $20 m+12 s t+16 a$ & - & - & Grazyna et al. (2008) \\
\hline & 48 & $80-81$ & $16 m+16 s m+15 a(16 a)$ & - & - & Grazyna et al. (2008) \\
\hline Colisa labiosa & 48 & 68 & $20 m+10 s t+18 a$ & - & - & Grazyna et al. (2008) \\
\hline \multirow{4}{*}{ Colisa lalia } & 46 & 70 & $24 \mathrm{msm}+22 \mathrm{a}$ & - & - & Grazyna et al. (2008) \\
\hline & 45 & - & $26 \mathrm{~m} / \mathrm{sm} / \mathrm{st}+19 \mathrm{a}$ & - & - & Grazyna et al. (2008) \\
\hline & 46 & 66 & $20 m+8 s t+18 a$ & - & - & Grazyna et al. (2008) \\
\hline & 16 & 30 & $14 m+2 a$ & - & - & Grazyna et al. (2008) \\
\hline Ctenops nobilis & 44 & 60 & $8 m+8 s m+28 t$ & - & - & Arai (2011) \\
\hline \multirow{2}{*}{ Macropodus ocellatus } & 46 & 54 & $4 m+4 s m+38 t$ & - & - & Arai (2011) \\
\hline & 46 & 76 & $8 m+8 s m+14 a+16 t$ & - & - & Arai (2011) \\
\hline \multirow[t]{3}{*}{ Macropodus opercularis } & 46 & 78 & $8 m+8 s m+16 a+14 t$ & - & - & Arai (2011) \\
\hline & 46 & 72 & $4 m+10 s m+12 a+20 t$ & - & - & Arai (2011) \\
\hline & 46 & 58 & $12 \mathrm{~m} / \mathrm{sm}+34 \mathrm{a} / \mathrm{t}$ & - & - & Arai (2011) \\
\hline Macropodus chinensis & 46 & - & - & - & - & Grazyna et al. (2008) \\
\hline Macropodus concolor & 46 & 56 & $10 m+2 s m+22 s t+12 a$ & - & - & Grazyna et al. (2008) \\
\hline Macropodus ocellatus & 46 & 64 & $8 m+8 s m+14 s t+16 a$ & - & - & Grazyna et al. (2008) \\
\hline \multirow[t]{2}{*}{ Macropodus opercularis } & 46 & 58 & $12 \mathrm{~m} / \mathrm{sm}+34 \mathrm{a}$ & - & - & Grazyna et al. (2008) \\
\hline & 46 & 64 & $8 m+8 s m+16 s t+14 a$ & - & - & Grazyna et al. (2008) \\
\hline Macropodus spechti & 46 & 80 & $10 m+2 s m+22 a+12 t$ & - & - & Arai (2011) \\
\hline Osphronemus gorami & 48 & 50 & $2 \mathrm{sm}+46 \mathrm{t}$ & - & - & Arai (2011) \\
\hline Parospromenus sumatranus & 46 & 46 & $46 \mathrm{t}$ & - & - & Arai (2011) \\
\hline \multirow[t]{2}{*}{ Sphaerichthys osphromenoides } & 16 & 30 & $14 \mathrm{~m} / \mathrm{sm}+2 \mathrm{t}$ & - & - & Arai (2011) \\
\hline & 16 & 30 & $10 m+4 s m+2 t$ & - & - & Arai (2011) \\
\hline \multirow{3}{*}{ Trichogaster chuna } & 46 & 64 & $10 m+8 s m+28 t$ & - & - & Arai (2011) \\
\hline & 46 & 80 & $20 m+8 s m+6 a+12 t$ & - & - & Arai (2011) \\
\hline & 46 & 86 & $28 m+12 s m+6 t$ & - & - & Arai (2011) \\
\hline \multirow[t]{9}{*}{ Trichogaster fasciata } & 48 & 86 & $16 m+16 s m+6 a+10 t$ & 2 & - & Arai (2011) \\
\hline & 48 & 75 & $15 m+12 s m / a+21 t$ & - & $\mathrm{ZW}, \mathrm{F}$ & Arai (2011) \\
\hline & 48 & 74 & $14 m+12 s m / a+22 t$ & - & $\mathrm{ZZ}, \mathrm{M}$ & Arai (2011) \\
\hline & 48 & 81 & $17 m+16 s m+15 t$ & - & $\mathrm{ZW}, \mathrm{F}$ & Arai (2011) \\
\hline & 48 & 80 & $16 m+16 s m+16 t$ & - & $\mathrm{ZZ}, \mathrm{M}$ & Arai (2011) \\
\hline & 48 & 83 & $15 m+16 s m+4 a+13 t$ & 6 & $\mathrm{ZW}, \mathrm{F}$ & Arai (2011) \\
\hline & 48 & 84 & $16 m+16 s m+4 a+12 t$ & - & $\mathrm{ZZ}, \mathrm{M}$ & Arai (2011) \\
\hline & 48 & 88 & $8 m+20 s m+12 a+8 t$ & - & - & Arai (2011) \\
\hline & 46 & 76 & $18 m+12 s m+16 t$ & - & - & Arai (2011) \\
\hline \multirow[t]{3}{*}{ Trichogaster labiosa } & 48 & 86 & $22 m+12 s m+4 a+12 t$ & - & - & Arai (2011) \\
\hline & 48 & 78 & $12 m+6 s m+12 a+18 t$ & - & - & Arai (2011) \\
\hline & 48 & 86 & $22 m+16 s m+10 t$ & - & - & Arai (2011) \\
\hline \multirow[t]{6}{*}{ Trichogaster lalius } & 45 & 71 & $14 m+12 s m / a+19 t$ & - & $\mathrm{ZO}, \mathrm{F}$ & Arai (2011) \\
\hline & 46 & 72 & $14 m+12 s m / a+20 t$ & - & $\mathrm{ZZ}, \mathrm{M}$ & Arai (2011) \\
\hline & 46 & 66 & $14 m+6 s m+26 t$ & - & $\mathrm{XX}, \mathrm{F}$ & Arai (2011) \\
\hline & 45 & 65 & $14 m+6 s m+25 t$ & - & $\mathrm{XO}, \mathrm{M}$ & Arai (2011) \\
\hline & 46 & 82 & $14 m+10 s m+12 a+10 t$ & - & - & Arai (2011) \\
\hline & 46 & 70 & $24 \mathrm{~m} / \mathrm{sm}+22 \mathrm{a} / \mathrm{t}$ & - & - & Arai (2011) \\
\hline \multirow[t]{2}{*}{ Trichopodus leeri } & 46 & 46 & $46 \mathrm{t}$ & - & - & Arai (2011) \\
\hline & 46 & 46 & $46 \mathrm{t}$ & - & - & Arai (2011) \\
\hline \multirow[t]{2}{*}{ Trichopodus microlepis } & 46 & 46 & $46 \mathrm{t}$ & - & - & Arai (2011) \\
\hline & 48 & 48 & $48 \mathrm{t}$ & - & - & Arai (2011) \\
\hline Trichopodus pectoralis & 46 & 46 & $46 \mathrm{t}$ & - & - & Arai (2011) \\
\hline Trichogaster sumatranus & 48 & 48 & $48 \mathrm{st} / \mathrm{a}$ & - & - & Grazyna et al. (2008) \\
\hline \multirow[t]{5}{*}{ Trichopodus trichopterus } & 48 & - & - & - & - & Arai (2011) \\
\hline & 46 & 46 & $46 \mathrm{t}$ & - & - & Arai (2011) \\
\hline & 46 & 46 & $46 \mathrm{t}$ & - & - & Arai (2011) \\
\hline & 46 & 46 & $46 \mathrm{t}$ & - & - & Arai (2011) \\
\hline & 46 & 46 & $46 \mathrm{t}$ & 2 & - & Supiwong et al. (2010) \\
\hline
\end{tabular}

Note: 2n: diploid chromosome number; NF: the fundamental number; m: metacentric; sm: submetacentric; a: acrocentric; t: telocentric; M: male; and F: female 


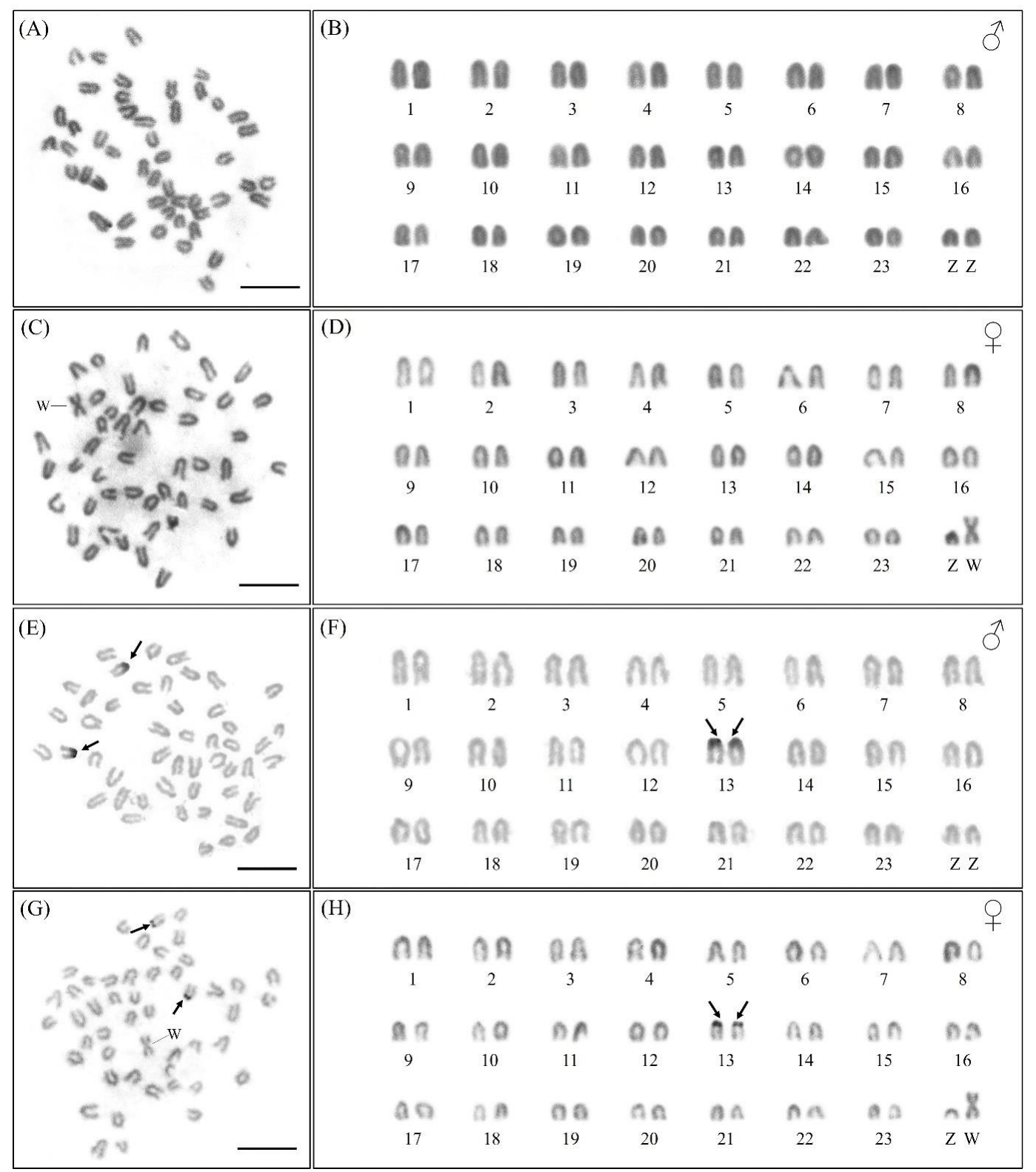

Figure 1. Metaphase chromosome plates and karyotypes of male (A-B and E-F) and female (C-D and G-H) Java combtail fish (Belontia hasselti), $2 \mathrm{n}=48$ by conventional straining (A-D) and Ag-NOR banding (E-H) technique. Scale bars indicate $5 \mu \mathrm{m}$. The arrows indicate nucleolar organizer regions/NOR

\section{Idiograms of Belontia hasselti chromosomes}

All previous results were summarized, and idiograms presenting shapes, sizes and probe signals on the chromosomes of $B$. hasselti are shown in Figure 3.

\section{Discussion}

The present study is the first one providing classical and molecular cytogenetics in the genus Belontia. The obtained results showed that the diploid chromosome number of $B$. hasselti was $2 \mathrm{n}=48$ for both sexes. It is the same as in some Osphronemidae species such as in Osphronemus goramy, Trichogaster fasciata, and Trichogaster labiosa (Grazyna et al. 2008; Arai 2011). However, it differs from most studied species in this family. The NFs were 48 and 49 in males and females, respectively (Figures 1-3). The different Osphronemidae species underwent an extremely diversified karyotype evolution, considering the numerical and structural aspects of their complements, with NF that varied from 20 to 88 (Arai 2011). Each chromosome pattern allows its utilization in the identification of visible changes on the karyotype macrostructure of several families in the order of Perciformes (Nirchio et al. 2002; Gustavo and Molina 2005; Roesti et al. 2013; Molina et al. 2014; Almeida et al. 2017). Analyses performed to highlight the combined importance of the different chromosome rearrangements in the evolutionary modeling of their karyotypes, such as Robertsonian rearrangements or centric fission, fusion, and especially, pericentric inversions were important roles for chromosomal rearrangements during evolution of Perciformes fishes 
(Ueno and Takai 2000; Jacobina et al. 2011). The occurrence of a large number of telocentric chromosomes in the karyotype is a common feature for Osphronemidae species, especially in the genus Trichopodus, and was also observed in the present study. However, this fish group is characterized by the occurrence of a non-conservative karyotype, with $2 \mathrm{n}$ ranging from 16 to 48 chromosomes (Table 1.).

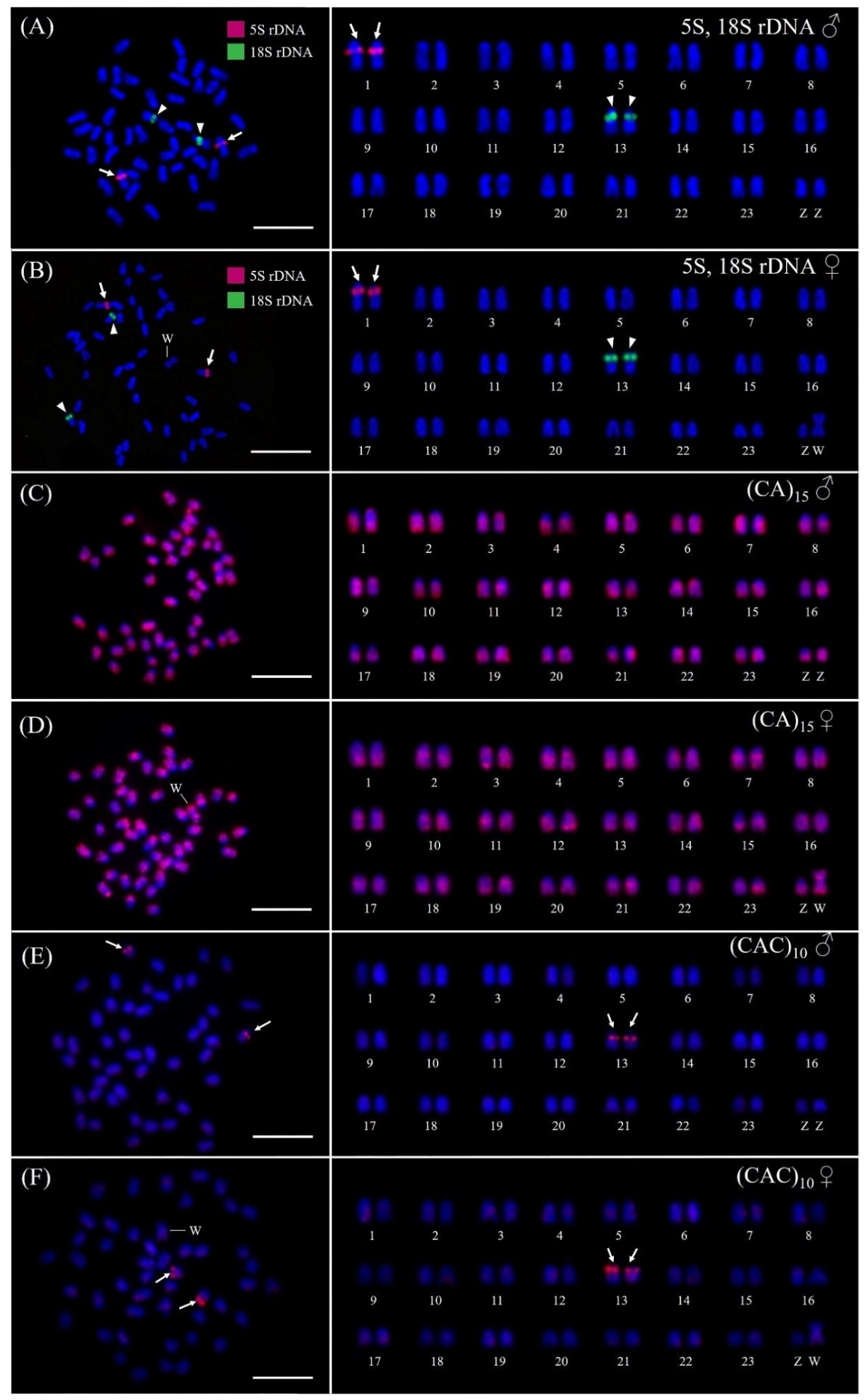

Figure 2. Karyotype of male (A, C, E) and female (B, D, F) Java combtail fish (Belontia hasselti), $2 \mathrm{n}=48$ arranged from chromosomes after double-fluorescence in situ hybridization (FISH) with $5 \mathrm{~S}$ rDNA (red) and $18 \mathrm{~S}$ rDNA (green) probes (A-B), FISH with d(CA) 15 probe $(\mathrm{C}-\mathrm{D})$, FISH with $\mathrm{d}(\mathrm{CAC})_{10}(\mathrm{E}-\mathrm{F})$. Bars indicate $5 \mu \mathrm{m}$. The arrows indicate probe signals 
(A)

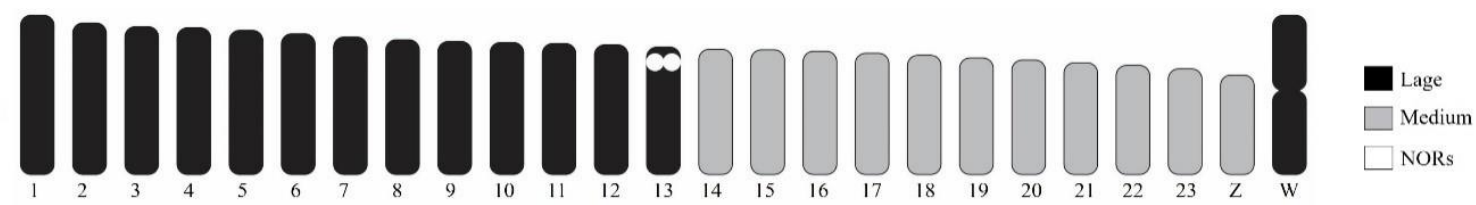

(B)

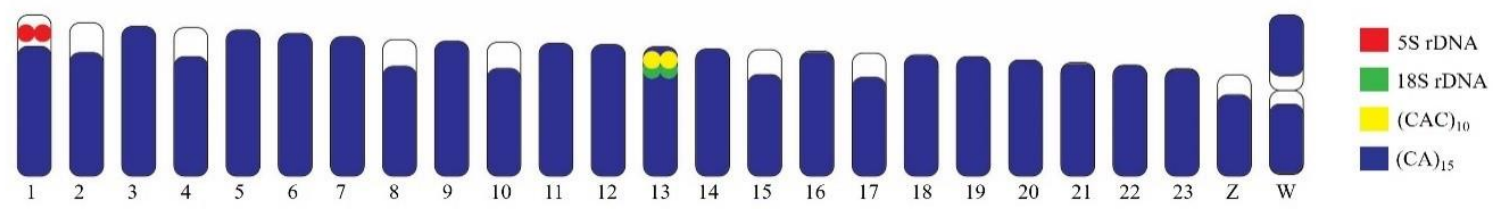

Figure 3. Idiograms of the Java combtail fish (Belontia hasselti), representing the haploid set $(n=23+\mathrm{ZW})$ by conventional staining, $\mathrm{Ag}-\mathrm{NOR}$ banding (A) and FISH (B) techniques

Table 2. Means of the short arm length (Ls), long arm length (Ll) and total arm length of chromosomes (LT), relative length (RL), centromeric index (CI) and standard deviation (SD) of RL, CI of 20 metaphase cells of the male and female Java combtail fish (Belontia hasselti), $2 \mathrm{n}=48$

\begin{tabular}{cccccccc}
\hline Chro. pair & LS & LL & LT & RL \pm SD & CI \pm SD & Chro. Size & Chro. Type \\
\hline 1 & 0.000 & 1.437 & 1.437 & $0.052 \pm 0.003$ & $1.000 \pm 0.000$ & Large & telocentric \\
2 & 0.000 & 1.368 & 1.368 & $0.050 \pm 0.003$ & $1.000 \pm 0.000$ & Large & telocentric \\
3 & 0.000 & 1.334 & 1.334 & $0.048 \pm 0.002$ & $1.000 \pm 0.000$ & Large & telocentric \\
4 & 0.000 & 1.324 & 1.324 & $0.048 \pm 0.002$ & $1.000 \pm 0.000$ & Large & telocentric \\
5 & 0.000 & 1.301 & 1.301 & $0.047 \pm 0.002$ & $1.000 \pm 0.000$ & Large & telocentric \\
6 & 0.000 & 1.270 & 1.270 & $0.046 \pm 0.002$ & $1.000 \pm 0.000$ & Large & telocentric \\
7 & 0.000 & 1.241 & 1.241 & $0.045 \pm 0.001$ & $1.000 \pm 0.000$ & Large & telocentric \\
8 & 0.000 & 1.216 & 1.216 & $0.044 \pm 0.001$ & $1.000 \pm 0.000$ & Large & telocentric \\
9 & 0.000 & 1.201 & 1.201 & $0.044 \pm 0.001$ & $1.000 \pm 0.000$ & Large & telocentric \\
10 & 0.000 & 1.192 & 1.192 & $0.043 \pm 0.001$ & $1.000 \pm 0.000$ & Large & telocentric \\
11 & 0.000 & 1.182 & 1.182 & $0.043 \pm 0.001$ & $1.000 \pm 0.000$ & Large & telocentric \\
12 & 0.000 & 1.171 & 1.171 & $0.043 \pm 0.001$ & $1.000 \pm 0.000$ & Large & telocentric \\
$13 *$ & 0.000 & 1.150 & 1.150 & $0.042 \pm 0.001$ & $1.000 \pm 0.000$ & Medium & telocentric \\
14 & 0.000 & 1.130 & 1.130 & $0.041 \pm 0.001$ & $1.000 \pm 0.000$ & Medium & telocentric \\
15 & 0.000 & 1.125 & 1.125 & $0.041 \pm 0.001$ & $1.000 \pm 0.000$ & Medium & telocentric \\
16 & 0.000 & 1.112 & 1.112 & $0.040 \pm 0.001$ & $1.000 \pm 0.000$ & Medium & telocentric \\
17 & 0.000 & 1.094 & 1.094 & $0.040 \pm 0.001$ & $1.000 \pm 0.000$ & Medium & telocentric \\
18 & 0.000 & 1.076 & 1.076 & $0.039 \pm 0.001$ & $1.000 \pm 0.000$ & Medium & telocentric \\
19 & 0.000 & 1.052 & 1.052 & $0.038 \pm 0.001$ & $1.000 \pm 0.000$ & Medium & telocentric \\
20 & 0.000 & 1.033 & 1.033 & $0.038 \pm 0.001$ & $1.000 \pm 0.000$ & Medium & telocentric \\
21 & 0.000 & 1.008 & 1.008 & $0.037 \pm 0.001$ & $1.000 \pm 0.000$ & Medium & telocentric \\
22 & 0.000 & 0.985 & 0.985 & $0.036 \pm 0.001$ & $1.000 \pm 0.000$ & Medium & telocentric \\
23 & 0.000 & 0.954 & 0.954 & $0.035 \pm 0.001$ & $1.000 \pm 0.000$ & Medium & telocentric \\
$\mathrm{Z}$ & 0.000 & 0.897 & 0.897 & $0.033 \pm 0.002$ & $1.000 \pm 0.000$ & Medium & telocentric \\
W & 0.680 & 0.757 & 1.437 & $0.052 \pm 0.018$ & $0.528 \pm 0.118$ & Large & metacentric \\
\hline
\end{tabular}

Remarks: Chro.: Chromosome, *: NOR-bearing chromosome

In a comparative karyotypic analysis of males and females in $B$. hasselti, the presence of a female-specific large metacentric chromosome pointed towards the occurrence of a ZZ/ZW sex chromosome system, where the $\mathrm{Z}$ chromosome is represented by a small-sized telocentric. Inside the Osphronemidae family, two other species, named $T$. fasciata and T. lalius also presented differentiated sex chromosomes. $T$. fasciata has the ZZ/ZW sex chromosome system in some populations, whereas $T$. lalius present variations of sex chromosome systems as ZZ/ZO and XX/XO (Arai 2011). The absence of differentiated sex chromosomes can be considered as a plesiomorphic feature
(Vicari et al. 2008). Although most Neotropical fish species do not have differentiated sex chromosomes, some other kinds of sex chromosome systems have already described in some families. In certain groups, such as some species of Anostomidae and Triportheinae, only the ZZ/ZW system was identified, while in other groups, such as Belontidae, Parodontidae and Erythrnidae, different sex chromosome systems were detected (Arai 2011; Cioffi et al. 2017). These results support the hypothesis of the differentiation of sex chromosomes in fishes having occurred independently in different groups (Almeida-Toledo et al. 2000). The presence of a sex chromosome system in the $B$. 
hasselti reinforces the evidence of divergent karyotypic evolution in this group.

B. hasselti is characterized by a single pair of AgNORs, located at the interstitial subcentromeric regions of pair 13 in both the sexes. The single pair of NOR-bearing chromosomes is in accordance with Trichopodus trichopterus, but differs for the NOR location in telomeric region of the telocentric pair 2 (Supiwong et al. 2010). However, intraspecific NOR polymorphisms can be seen in $T$. fasciata in which one and three homologous chromosomes with NORs were reported (Sobita and Bhagirath 2007; Kushwaha et al. 2008). In fishes, the location of NORs in a terminal position, and close to the centromere, is also pondered to be a primitive feature. Single NORs are widespread in several fish taxa (Gornung 2013; Sochorová et al. 2018). Species with multiple NORs are not rare among fishes (Martinez et al. 2010). The presented results here indicated a plesiomorphic or a primitive condition, whereas multiple pairs of NORs were suggested to be an apomorphic or derived condition (Milhomem et al. 2013).

Our results revealed that the $5 \mathrm{~S}$ rDNA and $18 \mathrm{~S}$ rDNA sequences were present at interstitial subcentromeric regions of pairs 1 and 13, respectively. For comparison with other species in the same family, only one species, $T$. trichopterus has so far been studied. The present results differ, as the 5S rRNA gene is located at a proximal region on a pair of medium-sized chromosomes, whereas the $18 \mathrm{~S}$ ribosomal gene is located at the telomeric region on long arms of the largest acrocentric pair (Pazza et al. 2009). Moreover, the $18 \mathrm{~S}$ rDNA signals were located on chromosome pair 13, which is consistent with NORs regions. The location of NORs has been confirmed by FISH using rRNA or rDNA probes in fixed chromosomes of several vertebrates, including amphibians, humans, chimpanzees (Sluisa et al. 2012; Hirai 2020), and more recently, fishes (Rubert et al. 2011; Milhomem et al. 2013; Fernandes et al. 2019). In higher eukaryotes, the moderately repetitive ribosomal RNA genes (rDNAs) are arranged in two different families: the nucleolus forming major (45S), and the non-nucleolus forming minor (5S) rDNAs. The major family is composed of the regions coding for $18 \mathrm{~S}, 5.8 \mathrm{~S}$ and $28 \mathrm{~S}$ rRNA genes, separated by internal transcribed spacers (ITS 1 and ITS 2), and surrounded by non-transcribed spacer (NTS) sequences (Singh et al. 2010). The nucleolar organizer regions contain $45 \mathrm{~S}$ rDNA gene cluster, which has also been studied employing $\mathrm{AgNO}_{3}$ and $\mathrm{CMA}_{3}$ staining. The minor family is composed of highly conserved 120 bp long coding sequences separated by a variable non-transcribed spacer (NTS) (Da Silva et al. 2012). Martins and Galetti Jr. (2001) propose that the 5S rDNA interstitial position is optimal for its organization in fishes, since it has been found in most species of several orders. For these reasons, the conservation of the $5 \mathrm{~S}$ rDNA distribution pattern may derive from the interstitial localization of these sites in the chromosomes.

The microsatellite repeats on the chromosomes of $B$. hasselti showed that $\mathrm{d}(\mathrm{CA})_{15}$ signals are present on all chromosome pairs, throughout the whole chromosomes except for centromeric regions of some pairs (pairs 2, 4, 8, 10,15 , and sex chromosome in both sexes), whereas, in most cases, they were found along the whole chromosomes. The patterns of $\mathrm{d}(\mathrm{CA})_{15}$ in $B$. hasselti are similar to Mystus species (Supiwong et al. 2013a) and Thai pufferfish Pao cochinchinensis (Pissaparn et al. 2020). In turn, this pattern is inconsistent with other fish, for example, the Hoplias malabaricus Bloch 1794, d(CA) $)_{15}$ probe signals provided a rich banding pattern in the subtelomeric region along most chromosome arms, while $\mathrm{d}(\mathrm{CA})_{15}$ had only slight accumulation on the sex chromosomes (X and Y) (Cioffi et al. 2011). In the Toxotes chatareus Hamilton 1822, the $\mathrm{d}(\mathrm{CA})_{15}$ repeats are abundantly distributed in all chromosomes, mostly in telomeric regions (Supiwong et al. 2017). From previous studies, it has been generally believed that microsatellites have specific zones as heterochromatin (telomeres, centromeres, and in the sex chromosomes) of fish genomes (Cioffi et al. 2011).

The pattern of $\mathrm{d}(\mathrm{CAC})_{10}$ hybridized to the autosomes at the interstitial subcentromeric region on chromosome pair 13, showed interaction with NOR sites, and overlap with patterns of $18 \mathrm{~S}$ rDNA in the present study. The pattern differs to that of $\mathrm{d}(\mathrm{CAC})_{10}$ on $\mathrm{H}$. malabaricus, producing a scattered distribution, and is thus more spread out along the autosomes. Furthermore, the microsatellite d(CAC) $)_{10}$ was uniformly spread along the $\mathrm{X}$ chromosome, with just some weak signals in the heterochromatic areas and on the $\mathrm{Y}$ chromosome were slightly accumulated in the centromeric and/or telomeric heterochromatic regions (Cioffi et al. 2011). However, microsatellites have also been found in non-centromeric regions, many of them located either near or within genes (Rao et al. 2010), as found in the present study.

In summary, here we provided the first (molecular) cytogenetic study of the $B$. hasselti, proposing the probable occurrence of a ZZ/ZW sex chromosome system, that needs further confirmation. The results obtained here can be used to support further investigation of taxonomy and evolutionary relationship among the family Osphronemidae and others.

\section{ACKNOWLEDGEMENTS}

The present work was supported by scholarship under the Post-Doctoral Training Program from Research Affairs and Graduate School, Khon Kaen University), Thailand (Grant no. 59255); Research and Technology Transfer Affairs of Khon Kaen University; and grant of Unit of Excellence 2020 on Biodiversity and Natural Resources Management, University of Phayao (UOE63005), Thailand.

\section{REFERENCES}

Almeida LAH, Nunes LA, Bitencourt JA, Molina WF, Affonso PRAM. 2017. Chromosomal evolution and cytotaxonomy in wrasses (Perciformes; Labridae). J Hered 108 (3): 239-253. DOI: $10.1093 /$ jhered/esx003. 
Almeida-Toledo LF, Foresti F, Toledo-Filho SA. 2000. Karyotypic evolution in neotropical freshwater fish. Chromosomes Today 13: 169-182.

Arai R. 2011. Fish Karyotypes: A Check List. Springer, Tokyo.

Chaiyasan P, Supiwong W, Saenjundaeng P, Seetapan K, Pinmongkhonkul S, Tanomtong A. 2018. A report on classical cytogenetics of highfin barb fish, Cyclocheilichthys armatus (Cypriniformes, Cyprinidae). Cytologia 83 (2): 149-154. DOI: 10.1508/cytologia.83.149

Chooseangjaew S, Tanyaros S, Maneechot N, Buasriyot P, Getlekha N, Tanomtong A. 2017. Chromosomal characteristics of the tropical oyster, Crassostrea belcheri Sowerby, 1871 (Ostreoida, Ostreidae) by conventional and Ag-NOR banding techniques. Cytologia 82: 3-8. DOI: $10.1508 /$ cytologia.82.3

Cioffi MB, Bertollo LAC, Villa MA, Oliveira EA, Tanomtong A, Yano CF, Supiwong W, Chaveerach A. 2015. Genomic organization of repetitive DNA elements and its implications for the chromosomal evolution of channid fishes (Actinopterygii, Perciformes). PLoS ONE 10 (6): e0130199. DOI: 10.1371/journal.pone.0130199.

Cioffi MB, Kejnovsky E, Bertollo LAC. 2011. The chromosomal distribution of microsatellite repeats in the genome of the wolffish Hoplias malabaricus, focusing on the sex chromosomes. Cytogenet Genome Res 132: 289-296. DOI: 10.1159/000322058.

Cioffi MB, Yano CF, Sember A, Bertollo LAC. 2017. Chromosomal evolution in lower vertebrates: sex chromosomes in neotropical fishes. Genes 8: 258. DOI: 10.3390/genes8100258.

Da Silva LLL, Giuliano-Caetano L, Dias AL. 2012. Chromosome studies of Astyanax jacuhiensis Cope, 1894 (Characidae) from the Tramandai river basin, Brazil, using in situ hybridization with the $18 \mathrm{~S}$ rDNA probe, DAPI and CMA3 staining. Folia Biol (Kraków) 60 (3-4): 13540. DOI: 10.3409/fb60 3-4.135-140.

Fernandes CA, Curiell MH, Paiz LM, Baumgärtner L, Piscor D, Margarido VP. 2019. A novel ZZ/ZW chromosome morphology type in Eigenmannia virescens (Gymnotiformes: Sternopygidae) from upper Paraná river basin. Biol 75: 1563-1569.

Froese R, Pauly D. 2014. Species of Belontia. In: Fish Base. www.fishbase.org.

Gálvez F, Symonová R, Kovařík A. 2018. Evolutionary trends in animal ribosomal DNA loci: Introduction to a new online database. Chromosoma 127: 141-150. DOI: 10.1007/s00412-017-0651-8.

Getlekha N, Supiwong W, Pinthong K, Sriuttha M, Kasiroek W, Tanomtong A. 2017. Chromosomal characteristics of the three-spot damselfish, Dascyllus trimaculatus (Perciformes, Pomacentridae) in Thailand. Cytologia 82 (1): 51-57. DOI: 10.1508/cytologia.82.51

Gornung E. 2013. Twenty years of physical mapping of major ribosoma RNA genes across the Teleosts: A review of research. Cytogenet Genome Res 141: 90-102. DOI: 10.1159/000354832.

Grazyna FS, Fopp-Bayat D, Jankun M, Krejszeff S, Mamcarz A. 2008. Note on the karyotype and NOR location of Siamese fighting fish Betta splendens (Perciformes, Osphronemidae). Caryologia 61 (4) 349-353. DOI: 10.1080/00087114.2008.10589646.

Gustavo SL, Molina WF. 2005. Karyotype diversification in fishes of the Balistidae, Diodontidae and Tetraodontidae (Tetraodontiformes). Caryologia 58: 229-237. DOI: 10.1080/00087114.2005.10589455

Hirai H. 2020. Chromosome dynamics regulating genomic dispersion and alteration of nucleolus organizer regions (NORs). Cells 9: 971. DOI: 10.3390/cells9040971

Jacobina UP, Cioffi MB, Souza LGR, Calado LL, Tavares M, Manzella JrJ, Bertollo LAC, Molina WF. 2011. Chromosome mapping of repetitive sequences in Rachycentron canadum (Perciformes: Rachycentridae): Implications for karyotypic evolution and perspectives for biotechnological uses. J Biomed Biotechnol 2011: 218231. DOI: $10.1155 / 2011 / 218231$

Kasiroek W, Indananda C, Luangoon N, Pinthong K, Supiwong W, Tanomtong A. 2017. First chromosome analysis of the Humpback cardinalfish, Fibramia lateralis (Perciformes, Apogonidae). Cytologia 82 (1): 9-15. DOI: 10.1508/cytologia.82.9.

Kottelat M. 2013. The fishes of the inland waters of Southeast Asia: A catalogue and core bibliography of the fishes known to occur in freshwaters, mangroves, and estuaries. Raffles Bull Zool 27: 1-663.

Kushwaha B, Kumar R, Nagpure NS, Behera BK, Lakra WS. 2008. Chromosome banding in two freshwaters gouramies from northeastern India. Nucleus 51: 61-72.

Maneechot N, Yano CF, Bertollo LAC, Getlekha N, Molina WF, Ditcharoen S, Tengjaroenkul B, Supiwong W, Tanomtong A, Cioffi MB. 2016. Genomic organization of repetitive DNAs highlights chromosomal evolution in the genus Clarias (Clariidae, Siluriformes). Mol Cytogenet 9: 4. DOI: 10.1186/s13039-016-0215-2.

Martinez PA, Araujo WC, Molina WF. 2010. Derived cytogenetic traits, multiple NORs and B chromosomes in the compact karyotype of Canthigaster figueiredoi (Tetraodontiformes). Mar Genom 3: 85-89. DOI: 10.1016/j.margen.2010.07.001

Martins C, Galetti JrPM. 2001. Two 5S rDNA arrays in neotropical fish species: is it a rule for fishes? Genetica 111: 439-446. DOI: $10.1023 / \mathrm{A}: 1013799516717$

Milhomem SSR, Scacchetti PC, Pieczarka JC, Ferguson-Smith MA, Pansonato-Alves JC, O’Brien PCM, Foresti F, Nagamachi CY. 2013. Are NORs always located on homologous chromosomes? A FISH Investigation with rDNA and whole chromosome probes in gymnotus fishes (Gymnotiformes). PLoS ONE 8 (2): e55608. DOI: 10.1371/journal.pone.0055608.

Molina WF, Martinez PA, Bertollo LA, Bidau CJ. 2014. Evidence for meiotic drive as an explanation for karyotype changes in fishes. Mar Genom 15: 29-34. DOI: 10.1016/j.margen.2014.05.001.

Nirchio M, Turner BJ, Perez JE, Gaviria JI, Cequea H. 2002. Karyotypes of three species of toadfish (Batrachoididae: Teleostei) from Venezuela. Sci Mar 66 (1): 1-4. DOI: 10.3989/scimar.2002.66n11

Pazza R, Kavalco KF, Penteado PR, Kavalco SAF, Almeida-Toledo LF. 2009. Gene mapping of $18 \mathrm{~S}$ and $5 \mathrm{~S}$ rDNA genes in the karyotype of the three-spot gourami Trichogaster trichopterus (Perciformes, Osphronemidae). Zebrafish 6 (3): 219-222. DOI: 10.1089/zeb.2009.0583.

Pissaparn M, Phimphan S, Chaiyasan P, Tanomtong A, Liehr T, Suwannapoom C, Reungsing M, Supiwong W. 2020. First chromosome analysis of Thai pufferfish Pao cochinchinensis (Steindachner, 1866). Biodiversitas 21 (9): 4309-4316. DOI: 10.13057/biodiv/d210949.

Rao SR, Trivedi S, Emmanue D, Merita K, Hynniewta M. 2010. DNA repetitive sequences-types, distribution and function: A review. J Cell Mol Biol 7 (2): 1-11.

Rodrigues DS, Rivera M, Lourenço LB. 2012. Molecular organization and chromosomal localization of 5S rDNA in Amazonian Engystomops (Anura, Leiuperidae). BMC Genet 13 (1): 17. DOI: 10.1186/14712156-13-17

Roesti M, Moser D, Berner D. 2013. Recombination in the threespine stickleback genome-patterns and consequences. Mol Ecol 22 (11): 3014-3027. DOI: $10.1111 / \mathrm{mec} .12322$.

Rubert M, da Rosa R, Jerep FC, Bertollo LAC, Giuliano-Caetano L. 2011. Cytogenetic characterization of four species of the genus Hypostomus Lacépède, 1803 (Siluriformes, Loricariidae) with comments on its chromosomal diversity. Comp Cytogenet 5 (5): 397-410. DOI: 10.3897/CompCytogen.v5i5.1589.

Singh M, Kumar R, Nagpure NS, Kushwaha B, Mani I, Murmu K, Chauhan UK, Lakra WS. 2010. Nucleotide sequences and chromosomal localization of $45 \mathrm{~S}$ and $5 \mathrm{~S}$ rDNA in Neolissochilus hexagonolepis (Pisces, Cyprinidae), using dual-color fish. Zoolog Sci 27 (8): 709-716. DOI: 10.2108/zsj.27.709.

Sluisa MV, Vuurena CV, Mangana H, McStaya B. 2012. NORs on human acrocentric chromosome p-arms are active by default and can associate with nucleoli independently of rDNA. Natl Acad Sci 117 (19): 10368-10377. DOI: 10.1073/pnas.2001812117.

Sobita N, Bhagirath T. 2007. Colisa fasciata (Schneider) (Perciformes, Anabantoidei, Belontidae) karyotype is divergent and ZW sex chromosomes are allocyclic and asynaptic. Nucleus 50: 45-49. DOI: 10.1007/s00412-017-0651-8.

Sochorová J, Garcia S, Gálvez F, Symonová R, Kovaří A. 2018. Evolutionary trends in animal ribosomal DNA loci: Introduction to a new online database. Chromosoma 127 (1): 141-150. DOI: 10.1007/s00412-017-0651-8.

Supiwong W, Jiwyam, Sreeputhorn K, Maneechot N, Bertollo LAC, Cioffi MB, Getlekha N, Tanomtong A. 2017. First report on classical and molecular cytogenetics of archerfish, Toxotes chatareus (Perciformes: Toxotidae). Nucleus 60 (3): 349-359. DOI: 10.1007/s13237-017-0216-5.

Supiwong W, Liehr T, Cioffi MB, Chaveerach A, Kosyakova N, Pinthong K, Tanee T, Tanomtong A. 2013a. Karyotype and cytogenetic mapping of 9 classes of repetitive DNAs in the genome of the naked catfish Mystus bocourti (Siluriformes, Bagridae). Mol Cytogenet 6 (1): 51. DOI: $10.1186 / 1755-8166-6-51$.

Supiwong W, Tanomtong A, Chaveerach A, Tanee T, Khakhong S, Sanoamuang L. 2013b. Interpopulational variation of NOR positions 
and karyotypic analysis of Siamese catfish (Pseudomystus siamensis) in Thailand. Cytologia 78 (1): 25-34. DOI: 10.1508/cytologia.78.25.

Supiwong W, Tanomtong A, Jumrusthanasan S, Khakhong S, Leelarasamee K, Sanoamuang L. 2012a. A first karyotype analysis and chromosomal characteristic of nucleolar organizer regions (NORs) in the common sheathfish, Micronema apogon (Siluriformes, Siluridae) in Thailand. Cytologia 77 (1): 53-58 DOI: $10.1508 /$ cytologia.77.53

Supiwong W, Tanomtong A, Kenthao A, Seetapan K, Kaewsri S. 2010 Standardized karyotype and ideogram of the three-spot gourami, Trichogaster trichopterus (Perciformes, Belontidae) from Thailand by conventional staining and Ag-NOR staining techniques. The Nucleus 53 (3): 103-107. DOI: 10.1007/s13237-011-0016-2.

Supiwong W, Tanomtong A, Pinthong K, Kaewmad P, Poungnak P, Jangsuwan N. 2015. The first chromosomal characteristics of nucleolar organizer regions and karyological analysis of pink anemonefish, Amphiprion perideraion (Perciformes, Amphiprioninae). Cytologia $\quad 80 \quad$ (3): $\quad 271-278$ DOI: $10.1508 /$ cytologia.80.271.
Supiwong W, Tanomtong A, Supanuam P, Jantarat S, Khakhong S, Leelarasamee K, Sanoamuang L. 2012b. A discovery of nucleolar organizer regions (NORs) polymorphism and karyological analysis of Smith's barb, Puntioplites proctozysron (Cypriniformes, Cyprinidae) in Thailand. Cytologia 77 (1): 35-42. DOI: 10.1508/cytologia.77.35.

Tanomtong A, Supiwong W, Jearranaiprepame P, Khakhong S, Kongpironchuen C, Getlekha N. 2014. A new natural autotetraploid and chromosomal characteristics of dwarf snakehead fish, Channa gachua (Perciformes, Channidae) in Thailand. Cytologia 79 (1): 1527. DOI: $10.1508 /$ cytologia.79.15.

Ueno K, Takai A. 2000. Chromosome evolution involving Robertsonian rearrangements in Xyrichthys fish (Labridae, Perciformes). Cytobios 103 (402): 7-15

Vicari MR, Artoni RF, Moreira-Filho O, Bertollo LAC. 2008 Diversification of a ZZ/ZW sex chromosome system in Characidium fish (Crenuchidae, Characiformes). Genetica 134 (3): 311-317. DOI: 10.1007/s10709-007-9238-2.

Xu D, Molina WF, Yano CF, Zhang Y, Oliveira EA, Lou B, Cioffi MB. 2017. Comparative cytogenetics in three Sciaenid species (Teleostei, Perciformes): Evidence of interspecific chromosomal diversification. Mol Cytogenet 10: 37. DOI: 10.1186/s13039-017-0338-0. 